\title{
Perbedaan Metode Peer Teaching dengan Metode Jigsaw Terhadap Tingkat Pengetahuan Kesehatan Reproduksi
}

\author{
Farina Anggraeni ${ }^{(1)}$, Tetti Solehati ${ }^{\left(2^{*}\right)}$, Wiwi Mardiah ${ }^{(3)}$ \\ ${ }^{1,2,3}$ Fakultas Keperawatan Universitas Padjadjaran Jatinangor Jawa Barat Indonesia. \\ ${ }^{(1)}$ anggraenifarina99@gmail.com; ${ }^{\left({ }^{*}\right)}$ tsh_tetti@yahoo.com; ${ }^{(3)}$ wimar09@gmail.com
}

\section{ARTICLE INFO A B S T R A C T}

Article history:

Received 17 March 2018

Revised 24 April 2018

Accepted 25 April 2018

Keyword:

Adolescent

Health Education

Reproductive Health

(*) corresponding author

DOI:http://dx.doi.org/10.30604/jika.v3i1.80
Adolescents are particularly vulnerable to the problem of the triad of adolescent reproductive health that includes sexuality, HIV/AIDS and drugs. Lack of knowledge among adolescents is one of the causes of risky behavior on reproductive health. Health education through peer teaching method and jigsaw method can improve knowledge and prevent adolescent reproductive health problems. The purpose of this research is to analyze the differences between the effects of peer teaching method with jigsaw method toward the level knowledge of reproductive health students SMPN 1 Cilegon. The research design is quasi-experiment with non equivalent control group. The research sample consisted of 42 respondents to the peer teaching group and 42 respondents to the jigsaw group which is chosen by stratified random sampling. The results of the analysis of statistical tests using $t$-dependent test shows that there is significant influence after being given health education with $p$ value $0.001(p<0.05)$ and the results $t$-independent test obtained $p$ value 0.021 ( $p<0.05)$, which shows the differences in effect between peer teaching method with jigsaw method toward the level knowledge of reproductive health students SMPN 1 Cilegon. The suggestion of this research is to use the jigsaw method as an alternative method in providing adolescent reproductive health education.

Copyright @ 2018, Jurnal Aisyah: Jurnal Ilmu Kesehatan.

\section{PENDAHULUAN}

Masa remaja merupakan masa peralihan dari masa kanak-kanak menuju masa dewasa, dimana remaja mengalami berbagai perubahan baik secara biologis, psikologis maupun kognitif. Secara umum, masa remaja ditandai dengan adanya pubertas yang merupakan suatu proses yang harus dilewati seseorang untuk mencapai kematangan seksual dan kemampuan untuk melakukan reproduksi (Feldman, 2009). Perubahan dan kematangan seksual yang dialami oleh remaja pada masa pubertas tersebut akan mengakibatkan munculnya kecemasan-kecemasan dan pertanyaanpertanyaan seputar menstruasi, mimpi basah, masturbasi, ukuran buah dada, penis 
dan lain sebagainya (Soetjiningsih \& Ranuh, 2015).

Tidak tersedianya informasi yang akurat dan benar tentang kesehatan reproduksi memaksa remaja untuk berusaha sendiri mencari akses dan melakukan eksplorasi sendiri. Pada umumnya remaja memanfaatkan media massa sebagai sumber informasi seksual yang lebih penting dibandingkan orang tua dan teman sebaya, karena media massa memberikan gambaran yang lebih baik dan menarik mengenai keinginan dan kebutuhan seksual remaja (Brown, 2003 dalam Supriati \& Sandra, 2009)

Pengetahuan remaja tentang kesehatan reproduksi remaja masih kurang sebagaimana ditunjukkan oleh hasil Survei Kesehatan Reproduksi Remaja Indonesia tahun 2007. Sebanyak 13 persen remaja perempuan tidak tahu tentang perubahan fisiknya dan hampir separuhnya yaitu 47,9 persen tidak mengetahui kapan masa subur seorang perempuan. Selain itu, pengetahuan remaja tentang menghindari infeksi HIV masih terbatas. Hanya 14 persen remaja perempuan dan 95 persen remaja laki-laki menyebutkan pantang berhubungan seks, 18 persen remaja perempuan dan 25 persen remaja laki-laki menyebutkan menggunakan kondom serta 11 persen remaja perempuan dan 8 persen remaja laki-laki menyebutkan membatasi jumlah pasangan (tidak berganti-ganti pasangan seksual) sebagai cara menghindari HIV/ AIDS (SKRRI, 2007).

Kurangnya pengetahuan dan pencarian informasi yang salah mengenai kesehatan reproduksi remaja dapat mempengaruhi perilaku beresiko pada remaja yang dikenal dengan tiga resiko kesehatan reproduksi remaja atau Triad Kesehatan Reproduksi Remaja (TRIAD KRR), yang meliputi seksualitas, HIV/AIDS dan Napza (BKKBN, 2007). Hal tersebut didukung oleh penelitian Lestary dan Sugiharti (2011) bahwa pengetahuan merupakan salah satu faktor yang berhubungan dengan perilaku beresiko pada remaja di Indonesia.

Provinsi Banten merupakan daerah yang berbatasan dengan DKI Jakarta yang merupakan salah satu provinsi yang memiliki kasus TRIAD KRR tinggi. Pada tahun 2010, sebanyak 6,5 persen dari 1.019.215 remaja di Provinsi Banten telah melakukan perilaku seksual yang tidak aman dan sebesar 77,2 persen remaja tidak mendapatkan penyuluhan kesehatan reproduksi (Riskesdas, 2010). Selain itu, berdasarkan data penelitian Puslitkes UI dengan BNN pada tahun 2011, angka penyalahgunaan Narkoba sebanyak 2,1 persen atau sekitar 172.901 dari 8.233.400 jiwa penduduk Provinsi Banten. Prevalensi tersebut berada pada urutan ke 9 dari 33 provinsi di Indonesia (BNN, 2014). Pada tahun 2012, kasus HIV/AIDS pada remaja di provinsi Banten sebanyak 13,4 persen dari 3.237 jiwa penduduk Provinsi Banten yang terkena HIV/AIDS. Provinsi Banten termasuk kategorik 10 besar tingkat nasional jumlah kasus HIV/AIDS (Depkes RI, 2012).

SMP Negeri 1 Cilegon merupakan salah satu instansi pendidikan di Kota Cilegon, Provinsi Banten. SMP Negeri 1 Cilegon Berdasarkan hasil wawancara dengan Guru BK SMP Negeri 1 Cilegon bahwa masih banyak siswa yang mencari informasi pendidikan kesehatan reproduksi melalui internet. Bahkan terdapat seorang siswa yang pernah menonton film porno dan melakukan onani/ masturbasi. Upaya yang dilakukan sekolah dalam meningkatkan kesehatan reproduksi remaja yaitu dengan memberikan layanan pendidikan kesehatan sebatas konseling individu yang bermasalah, padahal setiap siswa membutuhkan pendidikan kesehatan reproduksi. Selain itu, pihak sekolah juga memberikan pendidikan kesehatan reproduksi remaja dengan metode ceramah yang diberikan oleh petugas kesehatan dari puskesmas. Akan tetapi, pada pelaksanaan 
metode ceramah respon peserta didik tampak pasif.

Pemberian informasi dan pendidikan kesehatan yang dilakukan kepada beberapa siswa tersebut, menyebabkan penyebaran tentang informasi kesehatan di sekolah tidak merata dan berdampak pada tingkat pengetahuan siswa. Berdasarkan hasil wawancara yang dilakukan pada 10 siswa SMPN 1 Cilegon, diperoleh informasi bahwa 4 siswa mengetahui tentang kesehatan reproduksi meliputi seksualitas, HIV/AIDS dan Napza. Siswa tersebut menjawab bahwa perubahan yang terjadi pada masa remaja dipengaruhi oleh hormon, narkoba mengandung zat-zat yang berbahaya yang dapat merusak tubuh dan beresiko terkena HIV/AIDS. Sementara, 6 siswa mengaku tidak mengetahui tentang kesehatan reproduksi dan yang mereka tahu hanya kandungan dan bahaya pada rokok dan narkoba.

Permasalahan kesehatan reproduksi yang terjadi pada remaja tersebut menunjukkan bahwa remaja membutuhkan pelayanan kesehatan reproduksi. Pelayanan kesehatan reproduksi yang dibutuhkan remaja menyangkut hal-hal yang bersifat promotif dan preventif terfokus pada pelayanan konseling, edukasi dan informasi serta pelayanan kesehatan reproduksi secara khusus bagi remaja yang bermasalah dengan memberikan pelayanan sesuai kebutuhan dan masalahnya (Depkes RI, 2008). Berdasarkan penelitian yang dilakukan Widodo (2012) membuktikan bahwa remaja membutuhkan layanan kesehatan reproduksi yang dapat meminimalisasi dampak pergaulan remaja yang negatif sekaligus bisa menjadi tempat sosialisasi dan berkreasi bagi para remaja.

Perawat sebagai pemberi layanan asuhan keperawatan memiliki peran sebagai pendidik (educator) yang berfokus pada pendidikan kesehatan yang dianggap sebagai suatu fungsi didalam lingkup praktik keperawatan (Bastable, 2002)
Dalam pendidikan kesehatan dibutuhkan sebuah metode yang mampu meningkatkan fokus pembelajaran peserta didik sebagai sasarannya. Metode yang berkembang mampu meningkatkan pengetahuan, motivasi dan perubahan sikap pada peserta didik terhadap sebuah pembelajaran (Nursalam \& Effendi, 2009).

Metode yang dapat digunakan dalam pendidikan kesehatan yaitu metode pembelajaran aktif dengan pendekatan kooperatif dalam kelompok yang dilakukan oleh teman sebaya, sehingga peserta didik dapat saling bekerjasama dan mempengaruhi tingkat pengetahuan peserta didik lainnya (Daryanto dan Muljo, 2012).

Pendidikan kesehatan dengan metode pembelajaran aktif dapat menggunakan metode peer teaching yang merupakan salah satu metode pembelajaran yang aktif dan sesuai dengan perkembangan remaja, dimana remaja dapat memberikan dukungan serta pengaruh terhadap teman sebayanya (Bastable, 2002). Pada metode peer teaching siswa mengadopsi peranan guru pada proses pembelajaran. Metode ini juga menuntut siswa untuk saling belajar dan mengajar dalam kelompoknya (Dobobs \& Susan, 2006 dalam Palennari Hartati dan Syamsiah, 2008).

Dalam penerapan metode peer teaching terjadi proses membangun dan memberitahukan pengetahuan. Selain itu, metode tersebut dapat melatih dan meningkatkan kemampuan untuk mengeluarkan pendapat dan berkomunikasi serta melatih kemampuan siswa untuk kerjasama (Anggorowati, 2011). Akan tetapi, dalam penerapan metode ini ada beberapa orang siswa yang merasa malu dan enggan untuk bertanya karena takut kelemahannya diketahui oleh temannya dan siswa yang dibantu juga seringkali belajar kurang serius karena hanya berhadapan dengan temannya sendiri (Djamarah dan Zain, 2010). 
Selain itu, pendidikan kesehatan dapat dilakukan dengan metode jigsaw yang dikembangkan oleh Elliot Aroson (1978). Metode jigsaw merupakan proses belajar dan diskusi siswa dalam kelompok kecil dan siswa dituntut bekerja sama saling ketergantungan positif serta bertanggung jawab secara mandiri dalam memahami suatu materi (Daryanto dan Muljo, 2012). Menurut Fey \& Deyes (1989) dalam Bastable (2002), pembelajaran dalam kelompok yang terdiri dari anak berusia sebaya merupakan cara efektif untuk membantu remaja menghadapi tantangan kesehatan dan untuk mempelajari cara yang signifikan dapat mengubah perilaku.

Dalam metode jigsaw, peserta didik memiliki banyak kesempatan untuk mengemukakan pendapat dan mengelola informasi yang didapat, meningkatkan keterampilan berkomunikasi, dan bertanggung jawab atas keberhasilan pemahaman suatu materi. Selain itu, berdasarkan penelitian Sulastri dan Diana (2009), metode jigsaw juga dapat meningkatkan hasil belajar peserta didik yang signifikan. Akan tetapi pada pelaksanaan metode ini, terkadang didominasi oleh seseorang yang mengakibatkan peserta didik yang lain menjadi pasif (Rusman, 2008)

Pendidikan kesehatan reproduksi remaja melalui metode peer teaching dan metode jigsaw merupakan bentuk metode pembelajaran yang dapat meningkatkan pengetahuan tentang kesehatan reproduksi remaja, sehingga dapat mencegah permasalahan pada kesehatan reproduksi dan meningkatkan derajat kesehatan reproduksi remaja. Tujuan penelitian ini untuk menganalisis perbedaan pengaruh pendidikan kesehatan reproduksi metode peer teaching dengan metode jigsaw terhadap tingkat pengetahuan kesehatan reproduksi siswa SMPN 1 Cilegon.

\section{METODE}

Rancangan penelitian ini yaitu quasy experiment nonequivalent control group. Variabel independen pada penelitian ini adalah pendidikan kesehatan dengan metode peer teaching dengan metode jigsaw. Pendidikan kesehatan metode peer teaching dilakukan oleh tutor sebaya yang merupakan kader PIK KRR (Pusat Informasi dan Konseling Kesehatan Reproduksi Remaja) SMPN 1 Cilegon, yang telah diberikan pelatihan mengenai kesehatan reproduksi. Pendidikan kesehatan metode jigsaw dilakukan oleh seorang dosen dari bidang keperawatan.

Variabel dependen dalam penelitian ini adalah pengetahuan siswa tentang kesehatan reproduksi remaja meliputi, perkembangan seksualitas, HIV/AIDS dan NAPZA. Populasi pada penelitian ini sebanyak 506 siswa. Sampel pada penelitian ini sebanyak 84 responden dengan teknik stratified random sampling.

Alat pengumpulan data menggunakan kuesioner tertutup dengan menggunakan pilihan tunggal yang terdiri dari 4 alternatif jawaban mengenai pengetahuan kesehatan reproduksi yang memuat materi tentang tumbuh kembang remaja, organ reproduksi dan fungsinya, resiko hubungan seks pra nikah, pencegahan hubungan seks pra nikah, pengertian HIV/AIDS, cara penularan dan pencegahan HIV/AIDS, pengertian NAPZA, jenis NAPZA, pencegahan dan dampak penyalahgunaan NAPZA.

Kuesioner pengetahuan kesehatan reproduksi tersebut telah dilakukan uji validitas konten dengan menggunakan pendapat ahli pakar dari keperawatan maternitas dan keperawatan anak, serta dilakukan uji face validity instrument pada 20 siswa di SMPN 2 Cilegon. Uji realiabilitas kuesioner menggunakan rumus Kuder Richardson dengan nilai sebesar 0,71 yang menunjukkan item dalam instrumen reliabel. 


\section{HASIL DAN PEMBAHASAN}

Tabel 1 menunjukkan hasil distribusi frekuensi responden berdasarkan pengetahuan sebelum diberikan pendidikan kesehatan ditemukan bahwa pada kelompok peer teaching ada 26 orang (61,9 persen) maupun kelompok jigsaw ada 27 orang (64,3 persen) memiliki pengetahuan yang kurang mengenai kesehatan reproduksi remaja

Tabel 1. Distribusi Frekuensi Pengetahuan Sebelum Diberikan Pendidikan Kesehatan Pada Kelompok Peer Teaching dan Jigsaw, Mei 2016 (N=84)

\begin{tabular}{lcccc}
\hline \multirow{2}{*}{ Kategori Nilai } & \multicolumn{2}{c}{ Peer Teaching } & \multicolumn{2}{c}{ Jigsaw } \\
\cline { 2 - 5 } \multicolumn{1}{c}{ f } & \% & f & \% \\
\hline Kurang & 26 & 61,9 & 27 & 64,3 \\
Baik & 16 & 38,1 & 15 & 35,7 \\
\hline
\end{tabular}

Tabel 2 menunjukkan tingkat pengetahuan responden setelah diberikan pendidikan kesehatan dengan metode peer teaching dan metode jigsaw, didapatkan hasil bahwa hampir seluruh dari responden pada setiap kelompok memiliki pengetahuan yang baik yaitu sebanyak 37 orang $(88,1$ persen) pada kelompok peer teaching dan 40 orang $(95,2$ persen) pada kelompok jigsaw.

Tabel 2. Distribusi Frekuensi Pengetahuan Setelah Diberikan Pendidikan Kesehatan Pada Kelompok Peer Teaching dan Jigsaw, Mei $2016(\mathbf{N}=84)$

\begin{tabular}{lcccc}
\hline \multirow{2}{*}{ Kategori Nilai } & \multicolumn{2}{c}{ Peer Teaching } & \multicolumn{2}{c}{ Jigsaw } \\
\cline { 2 - 5 } & f & \% & f & \% \\
\hline Kurang & 5 & 11,9 & 2 & 4,8 \\
Baik & 37 & 88,1 & 40 & 95,2 \\
\hline
\end{tabular}

Pada tabel 3 menunjukkan adanya peningkatan pengetahuan responden pada kedua kelompok yaitu sebesar 14,37 pada kelompok peer teaching dan sebesar 16,37 pada kelompok jigsaw. Hasil analisa data berdasarkan uji $t$-dependent didapatkan $p$ value pada masing-masing kelompok adalah sebesar $0,000(\mathrm{p}<0,05)$, nilai tesebut menunjukkan adanya pengaruh yang sangat bermakna pendidikan kesehatan dengan metode peer teaching maupun metode jigsaw terhadap pengetahuan kesehatan reproduksi remaja.

Tabel 3. Perbandingan Pengetahuan Sebelum dan Sesudah Diberikan Pendidikan Kesehatan Pada Kelompok Peer Teaching dan Jigsaw, Mei 2016 (N=84).

\begin{tabular}{lccccc}
\hline & \multicolumn{2}{c}{ Peer Teaching } & \multicolumn{2}{c}{ Jigsaw } & \multirow{2}{*}{$\boldsymbol{p}$ value } \\
\cline { 2 - 5 } & Rata-rata & SD & Rata-rata & SD & \\
\hline Sebelum & 69,36 & 11,8 & 71,50 & 9,08 & \multirow{2}{*}{0,000} \\
Sesudah & 83,73 & 10,2 & 88,17 & 6,75 & \\
\hline
\end{tabular}

Tabel 4 merupakan hasil analisa data menggunakan uji t-independent yang menunjukkan adanya perbedaan antara metode peer teaching dan metode jigsaw terhadap tingkat pengetahuan kesehatan reproduksi dengan nilai $p 0,021(p<0,05)$. 
Tabel 4. Perbandingan Pengaruh Metode Peer Teaching dengan Metode Jigsaw Terhadap Tingkat Pengetahuan Kesehatan Reproduksi, Mei 2016 (N=84)

\begin{tabular}{lccc}
\hline & Mean & t & $\boldsymbol{p}$ \\
\hline Peer Teaching & 83,73 & 2,35 & 0,021 \\
Jigsaw & 88,17 & & \\
\hline
\end{tabular}

Hasil distribusi frekuensi pengetahuan tentang kesehatan reproduksi remaja antara kelompok peer teaching dengan kelompok jigsaw sebelum dilakukan pendidikan kesehatan menunjukkan bahwa sebagian besar dari responden berada dikategori kurang sebanyak 26 responden $(61,9)$ pada kelompok peer teaching dan 27 responden (64,3 persen) pada kelompok jigsaw. Hal tersebut menunjukkan bahwa jumlah responden baik pada kelompok peer teaching maupun kelompok jigsaw memiliki pengetahuan kurang yang hampir sama. Keadaan tersebut dapat disebabkan oleh faktor usia responden yang seluruhnya berada pada rentang usia yang sama yaitu usia 12-14 tahun yang termasuk pada masa remaja awal. Menurut Notoadmodjo (2003), semakin tua umur seseorang maka, semakin banyak pengetahuan yang dimilikinya. Dengan demikian, jumlah sebaran usia responden yang seluruhnya berada pada usia yang sama akan memiliki pengetahuan yang relatif sama.

Faktor lain yang juga mempengaruhi tingkat pengetahuan kesehatan reproduksi pada responden yaitu sumber informasi. Dalam penelitian ini, dari data yang diperoleh sebelum diberikan pendidikan kesehatan hampir seluruh dari responden memperoleh informasi internet $(85,7$ persen) sebagai media informasi yang cenderung satu arah dapat menjadi faktor seseorang memperoleh informasi yang kurang tepat, hal tersebut dikarenakan informasi yang diperoleh dapat dipersepsikan berbeda bahkan salah oleh penerima informasi dan dapat menimbulkan seseorang memiliki pengetahuan yang tidak tepat bahkan salah. Hal tersebut menunjukkan bahwa masih kurangnya informasi mengenai kesehatan reproduksi.
Pernyataan tersebut sejalan dengan BKKBN (2011), remaja seringkali kekurangan informasi dasar mengenai kesehatan reproduksi, dan keterbatasan dalam mengakses pelayanan kesehatan reproduksi.

Setelah diberikan pendidikan kesehatan terdapat peningkatan pengetahuan yaitu sebesar 14, 37 pada kelompok peer teaching dan sebesar 16, 37 pada kelompok jigsaw. Adanya peningkatan pengetahuan tersebut sesuai dengan pendapat menurut Budiman dan Agus (2013) tentang faktor yang mempengaruhi pengetahuan yaitu pendidikan yang merupakan suatu usaha mendewasakan manusia melalui upaya pengajaran. Pendidikan mempengaruhi proses belajar, semakin tinggi pendidikan maka, seseorang akan cenderung untuk mendapatkan informasi sehingga semakin banyak pengetahuan yang didapat dan menghasilkan perubahan dan peningkatan pengetahuan tentang kesehatan reproduksi. Selain itu, hasil penelitian ini juga sesuai dengan penelitian yang dilakukan Wahyuningsih (2015), bahwa adanya pengaruh pendidikan terhadap perubahan pengetahuan mahasiswa tentang TRIAD Kesehatan Reproduksi Remaja (KRR) dengan $p$ value $0,007(p<0,05)$.

Adanya peningkatan pengetahuan kesehatan reproduksi tersebut juga dipengaruhi oleh metode pembelajaran yang dilakukan. Metode peer teaching dan metode jigsaw merupakan metode pembelajaran aktif yang dilakukan oleh responden yang mempunyai usia sebaya. Pembelajaran dengan anggota kelompok usia sebaya tersebut dapat memberikan kenyamanan dan suasana lebih terbuka. Hal ini sesuai dengan pendapat dari Hurlock (2004) bahwa remaja memiliki 
kecenderungan untuk berada lebih nyaman dan terbuka kepada teman sebayanya, mereka dapat saling belajar satu sama lain dengan lebih efektif karena mereka merasa bahwa pengalaman mereka berada pada intrim yang sama. Selain itu, penelitian ini sesuai dengan teori Fey dan Deyes (1989) bahwa pembelajaran dalam kelompok yang terdiri dari anak berusia sebaya merupakan cara efektif untuk membantu remaja menghadapi tantangan kesehatan dan untuk mempelajari cara yang signifikan dapat mengubah perilaku (Bastable, 2002).

Selain itu, berdasarkan perhitungan uji $t$ dependent menunjukkan bahwa adanya pengaruh yang sangat bermakna pendidikan kesehatan pada kelompok metode peer teaching dengan kelompok jigsaw terhadap pengetahuan kesehatan reproduksi remaja dengan nilai $p$ value sebesar 0,000 ( $\mathrm{p}<$ $0,05)$.

Metode peer teaching merupakan metode pembelajaran aktif yang dilakukan oleh teman sebaya sehingga, responden dapat lebih nyaman dan terbuka dalam berpendapat mengenai kesehatan reproduksi. Selain itu, metode peer teaching memberikan kesempatan kepada responden untuk saling belajar dan mengajar dalam kelompoknya. Hal tersebut dapat mendorong responden untuk berpartisipasi secara aktif dalam pembelajaran sehingga, mempengaruhi tingkat pengetahuan responden tentang kesehatan reproduksi. Asumsi tersebut sesuai dengan penelitian yang dilakukan oleh Desmanita, Djuwitaningsih dan Rochimah (2014) bahwa terdapat pengaruh pendidikan kesehatan metode peer teaching terhadap pengetahuan kesehatan reproduksi dengan nilai $p$ value sebesar 0,003 .

Disamping itu, metode jigsaw juga merupakan pembelajaran aktif dengan pendekatan kooperatif, dimana setiap responden dituntut untuk saling ketergantungan positif dan bertanggung jawab atas penguasaan materi kesehatan reproduksi serta mampu mengajarkan materi kesehatan reproduksi kepada responden lain dalam kelompoknya. Aktivitas tersebut dapat meningkatkan tingkah laku kooperatif responden dalam pembelajaran dan mempengaruhi tingkat pengetahuan responden. Hal ini sejalan dengan penelitian yang dilakukan oleh Sulastri dan Rochintaniawati (2009) bahwa adanya pengaruh penggunaan pembelajaran kooperatif tipe jigsaw dalam pembelajaran biologi di SMPN 2 Cimalaka dengan skor gain ternormalisasi 0,44 yang tergolong pada kategori efektivitas sedang.

Hasil analisa data berdasarkan uji $t$ independent didapatkan $p$ value sebesar $0,021(p<0,05)$, nilai tesebut menunjukkan adanya perbedaan pengaruh metode peer teaching dengan metode jigsaw terhadap pengetahuan kesehatan reproduksi remaja. Metode jigsaw merupakan metode yang lebih efektif dibandingkan metode peer teaching. Perbedaan pada kedua metode tersebut juga dapat dilihat dari peningkatan rerata nilai responden setelah diberikan pendidikan kesehatan reproduksi remaja pada kedua kelompok perlakuan. Rerata nilai pengetahuan pada kelompok peer teaching meningkat sebesar 14,37 dan kelompok jigsaw meningkat sebesar 16,67.

Berdasarkan hasil penelitian ini, peneliti berasumsi bahwa secara umum peningkatan pengetahuan responden kelompok peer teaching dan kelompok jigsaw dipengaruhi oleh metode pembelajaran. Metode pembelajaran yang berbeda ini memberikan efek yang berbeda bagi responden terhadap tingkat pengetahuan. Hal ini sesuai dengan pendapat Mulyana (2005), bahwa tingkat keberhasilan penyampaian makna dari suatu pesan sangat dipengaruhi oleh metode yang tepat dan kemasan yang menarik dalam penyampaian pesan tersebut.

Pada metode jigsaw memberikan kesempatan kepada responden yang satu dengan yang lain untuk bertukar ide dan pendapat sehingga, hal ini dapat memperkaya pengetahuan yang mereka dapatkan. Dengan kata lain, pada metode 
jigsaw responden dapat berkomunikasi dua arah secara langsung dengan interaksi tatap muka dan keterampilan sosial yang dimiliki setiap responden. Selain itu, responden dituntut untuk bertanggung jawab atas penguasaan bagian materi kesehatan reproduksi dengan mampu mengajarkan materi tersebut kepada responden lain dalam kelompoknya. Hal tersebut memungkinkan meningkatnya keaktifan responden dalam pembelajaran dan pemahaman tentang pengetahuan kesehatan reproduksi. Asumsi tersebut sesuai dengan teori yang dikemukakan Felder dan Brent (2007) bahwa terdapat beberapa unsur dalam bekerja sama dan menyelesaikan suatu tujuan bersama dalam tim melalui metode jigsaw, yaitu saling ketergantungan positif, tanggung jawab individu, interaksi tatap muka dan keterampilan sosial (Warsono dan Hariyanto, 2012). Selain itu, hal tersebut sejalan dengan penelitian Setiani, Kade dan Lamba (2013) bahwa metode pembelajaran kooperatif tipe jigsaw membuat siswa lebih aktif dalam pembelajaran dan siswa lebih memahami materi.

Berbeda halnya dengan metode peer teaching, siswa hanya mendapatkan informasi dari satu informan yaitu tutor sebaya yang berasal dari kader PIK KRR yang merupakan teman sebaya yang lebih pandai memberikan informasi dan pengetahuan tentang kesehatan reproduksi. Selain itu, responden hanya dituntut untuk melihat materi pada slide power point di layar proyektor dan mendengarkan penjelasan dari tutor sebaya. Informasi yang disampaikan oleh tutor sebaya tersebut memungkinkan siswa yang diberikan informasi kurang serius dalam pembelajaran. Hal tersebut sesuai dengan pendapat Djamarah dan Zain (2010) bahwa pada metode peer teaching siswa yang dibantu sering belajar kurang serius karena hanya berhadapan dengan temannya sehingga, hasilnya kurang memuaskan. Keaktifan responden pada metode ini hanya saat siswa diberikan kesempatan bertanya pada sesi tanya jawab akan tetapi, tidak semua responden yang bertanya ataupun mampu untuk mengeluarkan pendapat.

Selain itu juga, hasil penelitian ini dapat diperkuat oleh teori Edgar Dale tentang kerucut pengalaman (Cone of Experience) yang menggambarkan kemampuan partisipan untuk mengingat kembali pesanpesan dalam pendidikan kesehatan berdasarkan teknik atau metodenya (Efendi dan Makhfudli, 2009). Pada metode jigsaw, seluruh responden berperan aktif dalam menyampaikan pendapat dan menyampaikan informasi yang telah didiskusikan, hal tersebut memungkinkan responden mengingat 70 persen dari apa yang diucapkannya. Sementara itu, pada metode peer teaching hanya satu orang saja yang memberikan penjelasan mengenai kesehatan reproduksi dan seluruh responden hanya mendengar dan melihat sehingga, memungkinkan responden hanya dapat mengingat 50 persen dari apa yang didengar dan dilihat. Oleh karena itu, hasil tingkat pengetahuan lebih banyak berdampak positif pada responden yang diberikan pendidikan kesehatan dengan metode jigsaw dibandingkan dengan metode peer teaching.

\section{KESIMPULAN DAN SARAN}

Hasil penelitian ini dapat disimpulkan bahwa berdasarkan uji t-independent menunjukkan adanya perbedaan pengaruh pendidikan kesehatan reproduksi metode peer teaching dengan metode jigsaw pada tingkat pengetahuan kesehatan reproduksi remaja dengan nilai $p$ value $=0,021$ $(p<0,05)$.

Metode jigsaw merupakan metode pembelajaran aktif yang lebih efektif dibandingkan dengan metode peer teaching, hal tersebut terjadi karena peran aktif responden dalam pendidikan kesehatan reproduksi dengan metode jigsaw lebih tinggi dibandingkan dengan metode peer teaching. Tenaga kesehatan dan 
instansi pendidikan dapat mengaplikasikan metode jigsaw sebagai metode alternatif dalam pembelajaran aktif, baik dalam bidang pendidikan kesehatan atau pun lainnya.

Metode jigsaw dapat diaplikasikan pada usia berbeda selain pada usia remaja, hal tersebut dikarenakan metode jigsaw memiliki unsur saling ketergantungan positif pada setiap peserta didik dalam pembelajaran. Peserta didik dapat berkomunikasi dua arah secara langsung dengan interaksi tatap muka dan keterampilan sosial yang dimiliki setiap peserta didik sehingga melibat seluruh peserta didik dalam pembelajaran dan dapat mempengaruhi tingkat pengetahuan. 


\section{DAFTAR PUSTAKA}

Anggorowati, N. P. (2011). Penerapan Model Pebelajaran Tutor Sebaya Pada Mata Pelajaran Sosiologi. Jurnal Komunitas Volume 3: 103-120.

Agustiani, H. (2009). Psikologi Perkembangan. Bandung: PT. Refika Aditama.

Arikunto. (2010). Prosedur Penelitian: Suatu Pendekatan Praktik. Jakarta: Rineka Cipta.

Bastable, S.B. (2002). Perawat sebagai Pendidik. Jakarta: EGC

BKKBN. (2006). Panduan Pengelolaan Pusat Informasi dan Konseling Kesehatan Reproduksi Remaja. Diakses dari http://www.bkkbn.go.id/

BKKBN. (2007). Kurikulum dan Modul Pelatihan Pengelolaan Pusat Informasi dan Konseling Kesehatan Reproduksi Remaja (PIK-KRR). Diakses dari http://www.bkkbn.go.id/

BKKBN. (2011). Kajian Profil Penduduk Remaja. Policy Brief Seri 1 Nomor 6. 1$4 . \quad$ Diakses dari http://www.bkkbn.go.id/litbang

BNN. (2014). Gelar FGD Evaluasi Penanganan Pecandu Narkoba di Banten. Diakses dari http://www.bnn.go.id/

Budiman dan Agus. (2013). Kapita Selekta Kuesioner: Pengetahuan dan Sikap dalam Penelitian Kesehatan. Jakarta: Salemba Medika.

Daryanto dan Muljo. (2012). Model Pembelajaran Inovatif. Yogyakarta: Gara Media.
Depkes RI. (2012). Profil Kesehatan Provinsi Banten Tahun 2012. Diakses dari www.depkes.go.id/

Depkes RI. (2008). Program Kesehatan Reproduksi dan Pelayanan Integratif di Tingkat Pelayanan Dasar. Diakses dari http://www.gizikia.depkes.go.id/

Djamarah, S. dan Zain, A. (2010). Strategi Belajar Mengajar. Jakarta: PT Rineka Cipta.

Efendi, F dan Makhfudli. (2009). Keperawatan Kesehatan Komunitas Teori dan Praktik dalam Keperawatan. Jakarta: Salemba Medika

Feldman, P.O. (2009). Human Development. Edisi 10. Jakarta: Salemba Humanika.

Hurlock, E.B. (2004). Psikologi Perkembangan. Jakarta: Erlangga.

Ikromah, Asmaningrum, dan Sulistiyorini. (2015). Perbedaan Metode Buzz Group Discussion dengan Peer teaching Audiovisual Terhadap Tingkat Pendidikan Warga Binaan Tentang HIV/AIDS di Lembaga Permasyarakatan Kelas IIA Kabupaten Jember. e-Jurnal Pustaka Kesehatan Volume 3 Nomor 1. 82-89.

Isjoni. (2007). Cooperative Learning Efektivitas Pembelajaran Kelompok. Pekan Baru: Alfabeta.

Kumalasari, I dan Iwan, A. (2012). Kesehatan Reproduksi untuk Mahasiswa Kebidanan dan Keperawatan. Jakarta: Medika Salemba.

Kusmiran, E. (2011). Kesehatan Reproduksi Remaja dan Wanita. Jakarta: Salemba Medika. 
Kozier, B., Erb, G., Berman, A., dan Snyder, S. (2011). Buku Ajar Fundamental Keperawatan Edisi 7 Volume 1. Jakarta: EGC.

Lestari, H dan Sugiharti. (2011). Perilaku Beresiko Remaja Di Indonesia Menurut Survey Kesehatan Reproduksi Remaja Indonesia (SKRRI) Tahun 2007. Jurnal Kesehatan Reproduksi, 1(3): 136-144.

Lie. (2002). Cooperative Learning. Jakarta: Gramedia Widiasarana Indonesia.

Mulyana, D. (2005). Ilmu Komunikasi Cetakan Ketujuh. Bandung: Rosdakarya.

Moedjiono. (1996). Proses Belajar Mengajar. Bandung: Remaja Rosdakarya.

Notoatmodjo, S. (2010). Ilmu Perilaku Kesehatan. Jakarta: Rineka Cipta.

Notoatmodjo, S. (2011). Kesehatan Masyarakat: Ilmu dan Seni. Jakarta: Rineka Cipta.

Nursalam. (2013). Metodologi Penelitian Ilmu Keperawatan Edisi 3. Jakarta: Salemba Medika

Nursalam dan Effendi, F. (2009). Pendidikan dalam Keperawatan. Jakarta: Medika Salemba.

Pinem, S. (2009). Kesehatan Reproduksi dan Kontrasepsi. Jakarta: Trans Info Media.

Palennari, M., Hartati, dan Syamsiah. (2008). Penerapan Metode Peer Group Teaching dalam Proses Pembelajaran Biologi untuk Meningkatkan Keaktifan dan Hasil Belajar Siswa Kelas X SMA Negeri 3
Makasar. Bionature Volume 9. 121125.

Riskesdas. (2010). Riset Kesehatan Dasar 2010. Diakses dari http://www.riskesdas.litbang.depkes.g o.id/

Rusman. (2008). Model-Model Pembelajaran: Mengembangkan Profesional Guru. Bandung: Rajawali Pers.

Simamora, R.H. (2009). Buku Ajar Pendidikan dalam Keperawatan. Jakarta: EGC.

SKRRI. (2007). Pendewasaan Usia Perkawinan dan Hak-Hak Reproduksi Bagi Remaja Indonesia. Diakses dari http://ceria.bkkbn.go.id/

Setiani, I., Kade, A., dan Lamba, H.A. (2013). Pengaruh Model Pembelajaran Kooperatif Tipe Jigsaw untuk Pengetahuan Awal yang Berbeda Terhadap Pemahaman Konsep Fisika Pada Siswa Kelas VIII SMP Negeri 9 Palu. Jurnal Pendidikan Fisika Tadulako 1(2):3238.

Slavin, R.E. (2005). Cooperative Learning: Cara Efektif dan Menyenangkan Pacu Prestasi Seluruh Peserta Didik. Bandung: Nusa Media.

Soetjiningsih dan IG.N. Gde Ranuh. (2015). Tumbuh Kembang Anak Edisi 2. Jakarta: EGC

Sugianto. (2010). Model-model Pembelajaran Inovatif. Surakarta: Yuma Pustaka.

Sugiyono. (2010). Metode Penelitian Kuantitatif, Kualitatif dan $R \& D$. Bandung: Alfabeta. 
Sulastri dan Diana. (2009). Pengaruh Penggunaan Pembelajaran Kooperatif Tipe Jigsaw dalam Pembelajaran Biologi di SMPN 3 Cimalaka. Jurnal Pengajaran MIPA. 13(1): 15-22.

Supriati, E. dan Sandra, F. (2009). Efek Paparan Pornografi Pada Remaja SMP Negeri Kota Pontianak Tahun 2008. Makara Sosial Humaniora, 13(1): 48- 56.

Wahyuningsih, M. (2015). Pengaruh Edukasi Terhadap Perubahan Pengetahuan dan Sikap Mahasiswa Tentang TRIAD Kesehatan Reproduksi Remaja (KRR) Di Fakultas Ilmu Sosial dan Ekonomi Universitas Respati Yogyakarta. Jurnal Keperawatan Respati. 1(2): 67-82.

Wasis. (2008). Pedoman Riset Praktis untuk Profesi Perawat. Jakarta: EGC.

Widodo, S.T.M. (2012). Analisis Kendala dan Kebutuhan Remaja Akan Layanan dan Pendidikan Kesehatan Reproduksi Remaja Di Daerah Istimewa Yogyakarta. Respati Medika. 10 (1):1-7.

Wong, D., Eaton, M., Wilson, D., Winkelstein, M., dan Schwartz, P. (2009). Buku Ajar Keperawatan Pediatrik Edisi 6. Jakarta: EGC. 